\title{
Personification as Manifestation of Author's Ironical Attitude from the Title-Text Correlation Standpoint (in the novel Animal Farm by G. Orwell)
}

\author{
Irina Mkhitaryan \\ Yerevan State University
}

\begin{abstract}
The paper attempts at presenting the author's ironical attitude in the allegorical novel "Animal farm" written by G. Orwell. Here we posit the idea that the author's ironical attitude can be embodied by personification, a figure of speech, which makes inanimate objects, animal characters or abstract ideas seem just like people by giving them human traits. The article also clarifies the role of context in defining the title-text correlation, which is best marked by the superiority of pigs ruling the farm instead of people. Hence, the former Manor Farm comes to be named Animal farm, postulating the abilities and strength of animals.
\end{abstract}

Key words: irony, personification, context, title-text correlation, modality.

\section{Introduction}

Animal farm is an allegory about life in the Soviet Union. The writer satirizes the political condition of the SU from 1917 to 1945 when Bolshevik party ruled over USSR. G. Orwell criticizes the political condition of Soviet Union at that time by using irony, which comes to be an important stylistic device being studied by many philosophers, linguists and rhetoricians. Numerous studies done in the field reveal mainly the pragmatic significance of the ironical speech. According to L. Breeva, the pragmatic essence of irony lies in its asymmetry, i.e. "what is said and what is implied" (Breeva 2000:131). Irony proves to be a highly intricate and context-bound type of communication. As D. Muecke puts it "irony is an art that gets its effects below the surface" (Muecke 1969:5). In this sense, scholars also mention that irony easily frustrates 
attempts at its elucidation through an investigation of its syntactic and semantic representations alone since all sentences are considered to be potentially ironic (Frust 1985; Sperber and Wilson 1989).

According to I. Galperin, "linguistic irony usually bears a negative meaning, notwithstanding the fact that it has a positive meaning in the dictionary (Galperin 1977:320). The capacity of irony to communicate what is offensive in an apparently non-offensive manner, given its duplicitous nature, qualifies it as "a successful way of avoiding censorship, whether the censor is a politician or superego" (Scholes 1982:75).

In recent linguistic studies the analyses of stylistic irony are mainly based on the principle of linguistic modality. There are numerous views on modality and its classification. The issues of modality, however, have thoroughly been studied in the works of V. Vinogradov and the most classic classification (objective and subjective modality) is stated to be his own. Objective modality is the relation of what is said by the speaker about the reality, but subjective modality is the attitude of the speaker to the content of expression (Vinogradov 1975:60). In this respect subjective modality introduces new ways of expressing irony. In general subjectivity plays a crucial role in how meaning is created and constructed. The French linguist $\mathrm{O}$. Ducrot developed his theory on irony, stating that one utterance can give access to several competing meanings with regard to which the speaker communicates his/her commitment or rejection. Ducrot's analysis requires a "split" of the speaker into several subjective instances (Ducrot 1984).

Ironic modality is expressed by many different literary devices, from which we have singled out personification. Personification is a term that was coined in the mid 1700s. It derives from the combination of the Greek (ānthrōpos) "human" and (morphē) "shape" or "form". It is a figure of speech used to give things a human form, to humanize inanimate objects, abstract entities, phenomena, and ideas (Dodwin 1990). According to H. Blair, people personify in order to express passionate emotions; personification is a sign of strong passions which "struggle for vent, and if they can find no other object, will rather than be silent, pour themselves forth" (Blair, 1983, quoted in Dodson, 2008). 


\section{Analysis of the Alegorial novel Animal farm from the Personification Point of View}

The novel Animal farm is a great masterpiece in personification and symbols. It is a very interesting, complex, and informative novel. The author uses farm animals to portray the people of power and the common people during the Revolution of the Socialists. The novel starts off with Major explaining to all the animals in the farm how they are being treated wrongly and how they can overthrow their owner, Mr. Jones. They finally gang up on their owner and he leaves the farm. Then, they start their own farm with their own rules and commandments. Originally the two people in charge of the Animal Farm are Napoleon and Snowball. Napoleon is really greedy and wants all the power to be his, so he gets the animals to turn on Snowball and make him leave the farm. After Napoleon took over the power, the pigs started disobeying the commandments. So the pigs disobeyed and changed every law that existed there started imitating humans. Although the animals cannot speak, write, plan, read or drink alcohol, they behave like humans, which makes the story more interesting and lively. Hence, personification becomes the key to the revelation of what is latent in the novel. Almost every character is a representation of an authority figure in Europe at that time. The author wants to depict the situation surrounding the Cold War, without actually naming those events or people.

As we have already mentioned, the novel is a satirical one, so G. Orwell uses irony to support his views. The main ironic theme which evolves throughout the entire novel, is the transition of the pigs into "human beings". At the start we have Old Major's clear vision of the future that outlaws humans and all their features. It goes against his ideals to copy human habits, but one by one the central rules are amended and then ignored. Before his death, the old Major warns the animals against mankind:

"Man serves the interests of no creature except himself... All men are enemies...And remember also that in fighting against Man, we must not come to resemble him... Do not adopt his 
vices... And, above all, no animal must ever tyrannize over his own kind .... All animals are equal."

(Orwell 1952:10-12)

G. Orwell uses irony and Major's words resonate throughout the novel, "all men are enemies we must not resemble them ... no animal must ever tyrannize his own" because they become the blueprint for Napoleon`s behavior once he has established his dominance over his own people. The commandments change as their hold over the animals changes and essentially erase the tenets of the revolution. Napoleon manipulates the animals into being more determined and faithful to their cause since they do not want to work under the tyranny of Jones or one of his agents. Yet, in the end, they are exchanging one tyrant for another.

The allegorical novel Animal farm brings in a considerable ironic force along with the author's severe criticism on Josef Stalin and his signature Stalinism. Nearly all the phenomena in the novel realize some symbolic nature which, in their turn, explicitly or impicitly express the author's ironic attitude. Through the use of allegory, the author tries to highlight the psychological pressure of revolution replacing one regime with another. Herein, G. Orwell criticizes those who do not firmly adhere to what they believe but blindly follow the revolutionaries, ignoring the evil and difficulties of future actions.

In the first chapter the following ideology that man is the enemy of animals is continuously propagated. The Old Major's words are revolutionary and it is the first time that the animals consciously admit to be the slaves of men, but don't have to be. However, the next chapters come to prove contrary views. Pigs try to walk upright, play cards and dance like men. They start to live in the farmhouse, adopting human vices. They start to walk with whips in their hands. Napoleon's insistence on the fact that the windmill should be built and re-built several times is suggestive of the establishment of his tyranny. His sole aim is to keep the masses busy so that he can easily rise to absolute power to terrorize his own kind. As time passes, Napoleon starts to lead a pleasant life while the working class is suffering. His ruling body turns out to exploit the animals more than Jones and the others did. In the end, irony reaches its peak. Old Major's doctrines are totally reversed. 
There, round the long table, sat half a dozen farmers and half a dozen of the more eminent pigs, Napoleon himself occupying the seat of honor at the head of the table. The pigs appeared completely at ease in their chairs.

(Orwell 1952:116)

Here we can notice the author's ironic attitude towards some false slogans and statement of humanity. This very attitude is sharply expressed through the device of personification. They start to live in the farmhouse, adopting human vices hence making it impossible to tell the pigs apart from the men.

It was a pig walking on his two legs. A little awkwardly, as though not quite used to supporting his considerable bulk in that position, but with perfect balance, he was strolling across the yard.

(Orwell 1952:113)

The animals that played the leading role during the revolution replace the human masters under whose oppression the animals suffered a great deal. Here it is worthy to mention D. Leyburn's statement on satire as "the revealing light of the allegorical satire is turned most searchingly upon the villainous hero himself: and when he is allowed to go off triumphant in the end, the feeling is that the wicked ways of the world have been convincingly displayed" (Leyburn 1962:219).

Napoleon (the pig) was now never spoken simply as "Napoleon". He was always referred to in formal style as "our Leader, Comrade Napoleon", and the pigs liked to invent for him such titles as Father of All Animals, Terror of Mankind, Protector of the Sheepfold, Ducklings Friend, and the like.

(Orwell 1952:80)

In this example the word leader shows that the pigs think of themselves as if they are teachers and they even have their headquarters soon after. We see pigs use their intelligence to trick the other animals and play mind games with them. 
The company had been enjoying a game of cards, and had broken off for a moment, evidently in order to drink a toast. A large jug was circulating, and the mugs were being refilled with beer. There were shoutings, bangings on the table, sharp suspicious glances, furious denials. The source of the trouble appeared to be that Napoleon and Mr. Pilkington had each played an ace of spades simultaneously.

(Orwell 1952:120)

All the above mentioned examples depict the device personification characterising the author's criticism on humans' stupidity or vices in the context of politics.

The corruption of absolute power is a major theme in the novel, as most of the animals hope to create a utopian system based on the equalty of all animals. The pigs manipulate and intimidate the other animals into subservience. G. Orwell underlines the basic tenet of human nature: some will always exist who are more ambitious, ruthless and willing to grab power than the rest of the society, and some within the society will be willing to give up power for security, therefore. The author gives the animals human qualities to further his satire. Napoleon is an absolute dictator who abuses the goodwill of the animals and Boxer is a strong, determined, faithful worker.

The story is told from the viewpoint of the animals in such a way as to enable the reader to like the animals, but at the same time to realize that their ideals are doomed. G. Orwell creates ironic distance because we can see the plotting of the pigs which the others cannot. The author wants us to see that unchecked good intentions are certain to turn into evil, and the promised land, ironically, is no better than the hell they were living before.

To put in a nutshell, the historical context of the novel reveals the intentions of G. Orwell as well. Through a humorous and effective animal allegory, G. Orwell directs his satiric attack on the events of the Revolution of the Soviet Union and on the totalitarian regime. The book reflects events leading up to the Soviet Union Revolution of 1917 and then on into the Stalinist era of the Soviet Union. G. Orwell substitutes animals for humans, so the major 
concepts of communism are played out on the farm. Communism is meant to be a classless society, yet the revolution of the Russians results in new leaders, but the same kind of tyrants. The same is manifested on the farm: pigs take over because they think of themselves as the smartest, and in order to protect them, it is eventually decided to reserve the best food for them. The Russian leaders, too, felt that they were equal to their fellow revolutionaries, but more privileged than the others, and deserved to be better fed than those producing the food.

\section{Conclusion}

By the way of conclusion, we can firmly posit that personification being the attribution of human characteristics to any inanimate object, abstract concept or impersonal is extensively used by G. Orwell in his novel Animal Farm. Personification is a literary device serves to decorate or amplify, to educate or clarify, to motivate or manipulate, to expose the cause or to deflect attention away from an insufficient system. The context enables us to highlight the "titletext" correlation, postulating the animals' abilities and strength. It is best illustrated by the fact that the former Manor Farm comes to be named Animal farm. It is not accidental that the author has chosen this title by conveying ironic force through skillfully representing the "title-text" correlation.

\section{References:}

1. Beers, H. (1996) Outline Sketch of English Literature. London: OUP.

2. Breeva, V. (2000) Sintaksicheskie sredstvo sozdania ironii. // Romanogermanskaya filologiya regulyativi, Vip.1 Saratov: Izdatel'stvo Sarat.un-ta.

3. Dodson, J. ( 2008) The Power of Personification: Rhetorical Purpose in The Book of Wisdom and The Letter to The Romans. NY: Walter de Gruyter.

4. Galperin, I. (1977) Stylistics. M.: Higher School.

5. Leyburn, D. (1962) Two Allegorical Treatments of Man: // Rasselas and La Peste,"Criticism: Vol. 4: Iss. 3, Article 3.

6. Muecke, D. (1969) The Compass of Iron. London: Methuen. 
7. Scholes, R. (1982) Semiotics and Interpretation. New Haven London: Yale University Press.

8. Sperber, D. and Wilson, D. (1981) Irony and the Use-mention Distinction'. // Radical Pragmatics. / Ed. by P. Cole. New York: Academic Press, pp. 298315.

9. Vinogradov, V. (1975) O kategorii modal'nosti i modal'nix slovakh v ruskom yazike. // Issledovaniya po russkom grammatike. M.: Nauka.

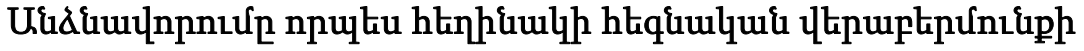

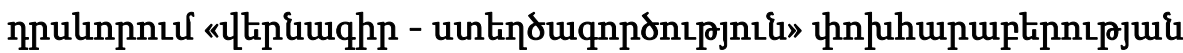

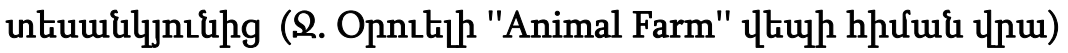

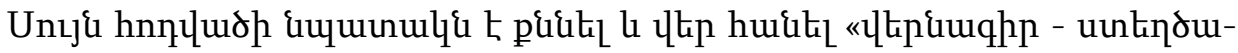

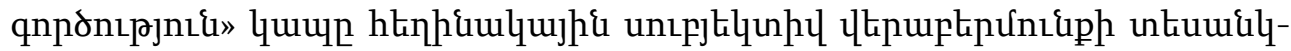

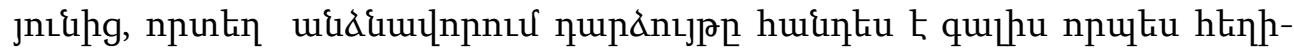

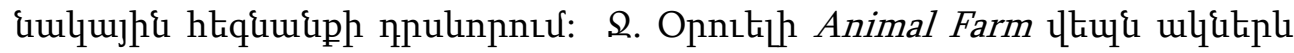

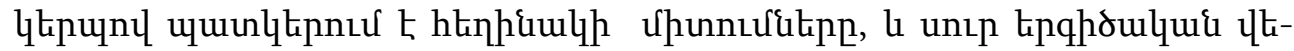

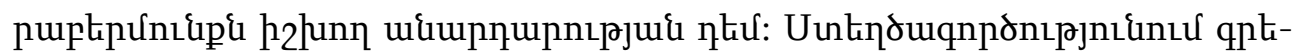

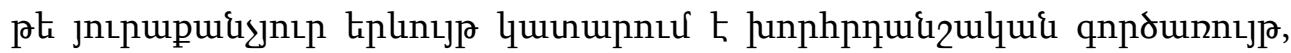

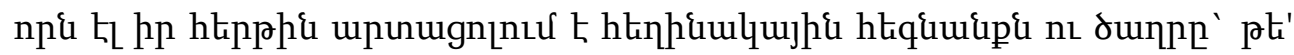

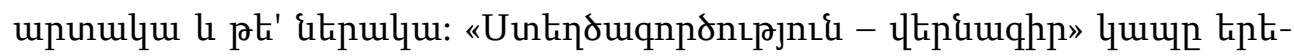

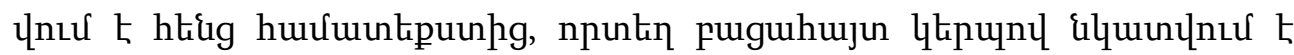

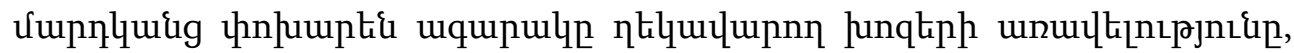

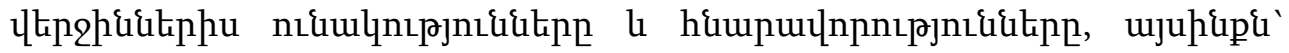

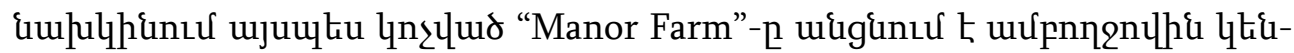

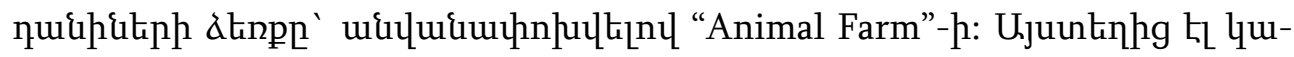

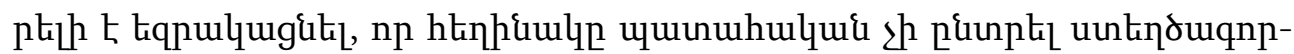

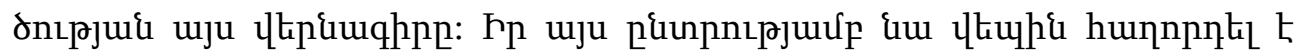

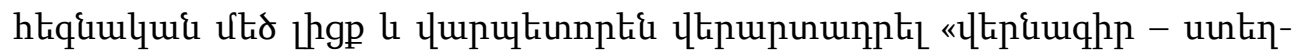

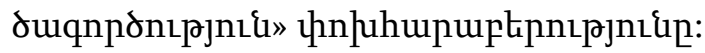

